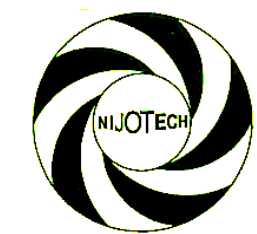

Nigerian Journal of Technology (NIJOTECH)

Vol. 39, No. 2, April 2020, pp. 613 - 620

Copyright@ Faculty of Engineering, University of Nigeria, Nsukka

Print ISSN: 0331-8443, Electronic ISSN: 2467-8821

www.nijotech.com

http://dx.doi.org/10.4314/njt.v39i2.33

\title{
YIELD, WATER USE AND WATER PRODUCTIVITY OF DRIP-IRRIGATED CUCUMBER IN RESPONSE TO IRRIGATION DEPTHS AND INTERVALS IN KADUNA, NIGERIA
}

\author{
E. J. Zakka1, N. E. Onwuegbunam ${ }^{2}$, A. Dare ${ }^{3}$, D. O. Onwuegbunam ${ }^{4, *}$ \\ and U. U. Emeghara ${ }^{5}$ \\ $\mathbf{1 , 3 , 4}$, Department of Agricultural \& Bio-EnVironmental ENGineERING, Forestry ReSEARCH INSTItUTE OF \\ Nigeria, Federal College of Forestry Mechanization, Afaka, Kaduna State, Nigeria

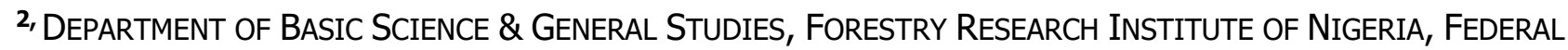 \\ COllege of Forestry MeChanization, Afaka, Kaduna State, NIGERIA \\ 5, DePARTMENT OF CROP PRODUCTION TECHNOLOGY ForESTRY RESEARCH INSTITUTE OF Nigeria, FederaL \\ College of Forestry Mechanization, Afaka, Kaduna State, NIGERIA \\ E-mail addresses: 1 ezakks@gmail.com, 2 esoheanddona@gmail.com, \\ 3dareakinrinshola@yahoo.com, 4 donancy2001@yahoo.com, 57amakaopec@yahoo.com
}

\begin{abstract}
A study was carried out at the research farm of the Federal College of Forestry Mechanization, Afaka, Kaduna, Nigeria, to determine the effect of irrigation depths and intervals on the yield, crop water use and water productivity of drip-irrigated cucumber (market-more variety) in two irrigation seasons (2016/17 and 2017/18). Irrigation was scheduled using the reference evaporation data obtained from pan evaporation measurements taken within the experimental periods. The results showed a significant difference in both seasonal crop evapotranspiration and yield at $5 \%$ level of significance in both seasons. The highest yields (21 t/ha and $20.3 \mathrm{t} / \mathrm{ha}$ ) were obtained from the treatments with 100 ETo, irrigated daily (T1), while the lowest (15.5 t/ha and $16.5 \mathrm{t} / \mathrm{ha})$ were obtained from the treatments with $60 \% E T_{0}$, irrigated every four days (T9). The highest water productivities were obtained from the treatments with $60 \%$ ETo, irrigated daily (T7), while the lowest were obtained from the treatments with $100 \%$ ETo, irrigated every four days (T3), implying a better yield effect due to light high frequent irrigation than deep low frequent irrigation. The marginal difference in yield due to the marginal difference in water applied in $T 1$ and $T 7$ is $3.7 t / h a$. It is concluded that full irrigation produced higher yield than deficit irrigation but with lower crop water productivity.
\end{abstract}

Keywords: Cucumber yield, water use, water productivity, irrigation depth, irrigation interval

\section{INTRODUCTION}

Water is an essential factor in agricultural production all over the world. In the regions with low annual rainfall, irrigation becomes a necessity for crop production. Even in areas with sufficient seasonal rainfall, irrigation becomes essential during the dry season as more food needs to be produced for the teeming population. A major constraint to arable crop production is the availability of water, water often being a major limiting factor in regions of low rainfall or in agro-climatic zones where rainfall is unevenly distributed throughout the year. Kaduna, Northwest, Nigeria has been categorized under the semi-arid region of Africa, characterized by relatively low precipitation, where irrigation practice is a must for sustainable agriculture [1]. The production of out-ofseason vegetables like cucumber requires supplemental or total water application. In Kaduna,

* Corresponding author, tel: +234-802-378-6572 
Nigeria, an abundant supply of water is not available during the dry period (typically from November to April), hence water conservation and maximizing its use for irrigation is crucial for sustainable economic production of vegetable and other irrigable crops. Limited water for crop production makes growers seek ways to save water by increasing irrigation efficiencies.

With drip (or trickle) irrigation, water is conveyed under pressure through a pipe system to the fields, where it drips slowly onto the soil through emitters or drippers which are located close to the plants. Compared to other types of irrigation (sprinkler irrigation or surface irrigation), only the immediate root zone of each plant is wetted. In addition, drip can eliminate many diseases that are spread through irrigation water. Drip irrigation is adaptable to any farmable slope and is suitable for most soils. Therefore this can be a very efficient method of irrigation.

Irrigation interval is very crucial in drip irrigation management as it affects soil moisture and root distributions as well as water uptake by plants [2]. Cao et al. [3] have indicated that irrigation frequency can change the spatial distribution of soil moisture and soil-water storage. Low frequency irrigation corresponds to excessively long irrigation intervals and may cause moisture stress, especially in sandy soil textures. On the other hand, an excessively high irrigation frequency can lead to desirable conditions for water uptake by roots, but at the expense of increased energy and labour costs [4], [5].

It is essential to determine the right amounts of water needed for plants during the growth cycles, and to develop the most suitable irrigation schedule to produce the optimum plant yield. Such schedules are developed for different ecological regions, as plant water consumption during the growth cycle depends mostly on plant growth, soil and climatic conditions [6]. Optimum irrigation scheduling based on water use patterns and crop response to water deficit can potentially improve the water productivity which is the ratio of the crop yield to seasonal water use, while the irrigation water productivity (IWP) is the ratio of the crop yield for a particular treatment to the applied water for that treatment [7].

Irrigation scheduling involves preventing the soil water deficit from falling below some threshold level for a particular crop and soil condition. This may involve estimating the earliest date to permit efficient irrigation or the latest date to avoid the detrimental effects of water stress on the crop [8]. Scheduling water application is very critical to make the most efficient use of drip irrigation system, as excessive irrigation reduces yield, while inadequate irrigation causes water stress and reduces production. Water shortage during the dry season in Kaduna has motivated vegetable farmers to adopt different water management strategies, one of which this study addresses.

Cucumber is among the most popular vegetables grown in the world today. Li and Wang [9]; Mao et al. [10] have stated that cucumber requires more water than grain crops. Cucumber plants need between $25 \mathrm{~mm}$ and $50 \mathrm{~mm}$ of water per plant per week for optimum production and fruit quality. The plants have higher demand for moisture during pollination and fruit development [11]; [12].

Based on the foregoing, the objective of the study is to determine the yield and water productivity of a determinate cucumber cultivar as affected by irrigation depths and intervals in Kaduna, Northwest Nigeria.

\section{MATERIALS AND METHODS}

\subsection{Description of Study Location and Period}

The study was carried out at the experimental field of the Federal College of Forestry Mechanization (FCFM), Afaka, Kaduna, Nigeria, located on latitude $10^{\circ} 37^{\prime} \mathrm{N}$ and longitude $7^{\circ} 47^{\prime} \mathrm{E}$, and situated in the Northern guinea savannah ecological zone of Nigeria. The study was carried out during the full irrigation seasons of 2016/2017 and 2017/2018; specifically $9^{\text {th }}$ February to $11^{\text {th }}$ April, 2018 for the former, and $23^{\text {rd }}$ February to $24^{\text {th }}$ April, 2018 for the latter. The prevailing weather conditions of the study area during the periods were obtained by measurement from the College meteorological station and are shown in Table $1(a)$ and (b).

\subsection{Experimental Design and Treatments}

A randomized complete block design (CRBD) with three replications was used in the study. The experimental treatment comprises two factors which are irrigation depth (I) and irrigation interval (T). I consist of three levels: $100 \% \mathrm{ET}_{0}, 80 \% \mathrm{ET}_{\mathrm{o}}$ and $60 \%$ $\mathrm{ET}_{\mathrm{o}}$, while $\mathrm{T}$ consists of three levels: irrigating daily (24-hourly), irrigating every other day (48-hourly) and irrigating every four days (96-hourly). Hence the experiment comprises nine treatments as described in Table 2. 


\subsection{Agronomic Practices}

The plant, cucumber (cucumber market-more variety) seeds were sown directly on rows at intrarow by inter-row spacing of $45.7 \mathrm{~cm} \times 100 \mathrm{~cm}$. The intra-row spacing was conformed to the emitter spacing of the drip tubings $(45.7 \mathrm{~cm})$. The plant population per hectare based on the plant spacing is 21,882 . The plant spacing suggested by [13] and [14], for open field cucumbers is $45-60 \mathrm{~cm}$ in-row x $120-150 \mathrm{~cm}$ between rows (equivalent to plant population of 15,000 to 20,000 plants per hectare) and $30 \mathrm{~cm}$ in-row $x 100 \mathrm{~cm}$ between rows (equivalent to 30,000 plants per hectare), respectively. The spacing adopted falls within these ranges. The plants were uniformly watered within the first two weeks after germination to establish them. Thereafter, the irrigation treatments were imposed. Figure 1 shows the pictorial view of a section of the experimental field.

Light weeding was manually carried out using hoes. Incidence of cutworm infestation was observed and this was controlled using kombat cypermethrin at the rate of $100 \mathrm{ml} / \mathrm{ha}$ [15].

\subsection{Irrigation Approach}

The plants were irrigated in the evenings based on treatments by means of a pressurized drip irrigation system with pressure compensating inline emitters. Water from an overhead reservoir was delivered under pressure to the drip lines via the mains and the sub-mains by means of a $1.5 \mathrm{hp}$ gasoline-powered centrifugal pump. The pump has $1000 \mathrm{l} / \mathrm{min}$ delivery capacity at total operational head of $30 \mathrm{~m}$. The pressure requirement for operating the drip lines as recommended by the manufacturers is 84 to $349 \mathrm{Kpa}$ (12 to 50 Psi). To indicate the system operation pressure, a pressure regulator was installed on the mains, close to the junction, before its branch-off to the sub-mains. Also a filter was installed on the mains, before the pressure gauge, to protect the system against particles which can clog the emitting points. After installation, the drip irrigation systems performance evaluation was carried out to determine its emission characteristics, which is required in computing the irrigation time for each treatment [16]. Irrigation was usually preceded by soil moisture monitoring to determine the soil moisture level before irrigation. Soil moisture measurements were also taken after irrigation to determine the amount of moisture depleted from the crop root zone in each treatment. Hence, the crop water evapotranspiration was as calculated by Michael [17]:

$$
\mathrm{ET}_{\mathrm{c}}=\frac{\sum_{\mathrm{i}=1}^{\mathrm{n}}\left(\mathrm{GMC}_{1 \mathrm{i}}-\mathrm{GMC}_{2 \mathrm{i}}\right) * \mathrm{~A}_{\mathrm{i}} * \mathrm{D}_{\mathrm{i}}}{\mathrm{t}}
$$

where, $\mathrm{ETC}=$ average daily evapotranspiration between successive soil moisture content sampling periods $\left(\mathrm{cm} /\right.$ day), $\left(G_{M C} C_{1 i}-G M C_{2 i}\right)=$ change in gravimetric soil moisture content $(\mathrm{g} / \mathrm{g})$ between two measurement dates in the ith soil layer; $\mathrm{Ai}=$ Bulk density of the $i^{\text {th }}$ layer; $D_{i}=$ depth of $i_{\text {th }}$ layer $(\mathrm{mm})$; $\mathrm{n}=$ number of soil layers sampled; $\mathrm{t}=$ number of days between successive soil moisture content sampling.

The soil moisture measurements were taken by means of a soil moisture meter at depths of $0-15 \mathrm{~cm}$, $15-30 \mathrm{~cm}$ and $30-45 \mathrm{~cm}$, using access tube to the deeper soil profiles. The moisture meter was calibrated to give the equation,

VM $(S L)=2.5082$ MMR

where, $\mathrm{VM}(\mathrm{SL})=$ Volumetric moisture content of sandy loam (\%) and MMR = Moisture meter reading (units).

Table 1a: Prevailing weather condition of FCFM Afaka, Kaduna (2017)

\begin{tabular}{llllllll}
\hline Month & $\begin{array}{l}\text { Max. } \\
\text { temp., oC }\end{array}$ & $\begin{array}{l}\text { Min. } \\
\text { temp., oC }\end{array}$ & $\begin{array}{l}\text { Relative } \\
\text { humidity, } \%\end{array}$ & $\begin{array}{l}\text { Wind speed, } \\
\text { km/day }\end{array}$ & $\begin{array}{l}\text { Sunshine } \\
\text { hour, hr. }\end{array}$ & $\begin{array}{l}\text { ETo, } \\
\mathrm{mm} / \text { day }\end{array}$ & $\begin{array}{l}\text { Rainfall, } \\
\mathrm{mm}\end{array}$ \\
\hline Feb. & 34 & 18.9 & 19 & 231 & 9.2 & 7.08 & 0 \\
Mar. & 36 & 21.5 & 18 & 185 & 9.5 & 7.04 & 0 \\
Apr. & 36 & 23 & 36 & 211 & 9.0 & 6.30 & 0 \\
\hline
\end{tabular}

Table 1b: Prevailing weather condition of FCFM Afaka, Kaduna (2018)

\begin{tabular}{llllllll}
\hline Month & $\begin{array}{l}\text { Max. } \\
\text { temp., }{ }^{\circ} \mathrm{C}\end{array}$ & $\begin{array}{l}\text { Min. } \\
\text { temp., }{ }^{\circ} \mathrm{C}\end{array}$ & $\begin{array}{l}\text { Relative } \\
\text { humidity, } \%\end{array}$ & $\begin{array}{l}\text { Wind speed, } \\
\mathrm{km} / \text { day }\end{array}$ & $\begin{array}{l}\text { Sunshine } \\
\text { hour, hr. }\end{array}$ & $\begin{array}{l}\text { ETo, } \\
\mathrm{mm} / \text { day }\end{array}$ & $\begin{array}{l}\text { Rainfall, } \\
\mathrm{mm}\end{array}$ \\
\hline Feb. & 38 & 23.4 & 21 & 222 & 9.6 & 7.58 & 0.0 \\
Mar. & 39.5 & 26.6 & 19 & 177 & 9.8 & 7.42 & 0.0 \\
Apr. & 36.2 & 23.1 & 37 & 205 & 9.1 & 6.40 & 0.0 \\
\hline
\end{tabular}


Table 2: Description of experiment

\begin{tabular}{lll}
\hline Treatment Number & Treatment tag & Treatment description \\
\hline T1 & I100T24 & Irrigating with $100 \%$ ETo daily (control). \\
T2 & I100T48 & Irrigating with $100 \%$ ETo every other day \\
T3 & I100T96 & Irrigating with $100 \%$ ETo every four days \\
T4 & I80T24 & Irrigating with $80 \%$ ETo daily \\
T5 & I80T48 & Irrigating with $80 \%$ ETo every other day \\
T6 & I80T96 & Irrigating with $80 \%$ ETo every four days \\
T7 & I60T24 & Irrigating with 60\% ETo daily \\
T8 & I60T48 & Irrigating with 60\% ETo every other day \\
T9 & I60T96 & Irrigating with 60\% ETo every four days \\
\hline
\end{tabular}

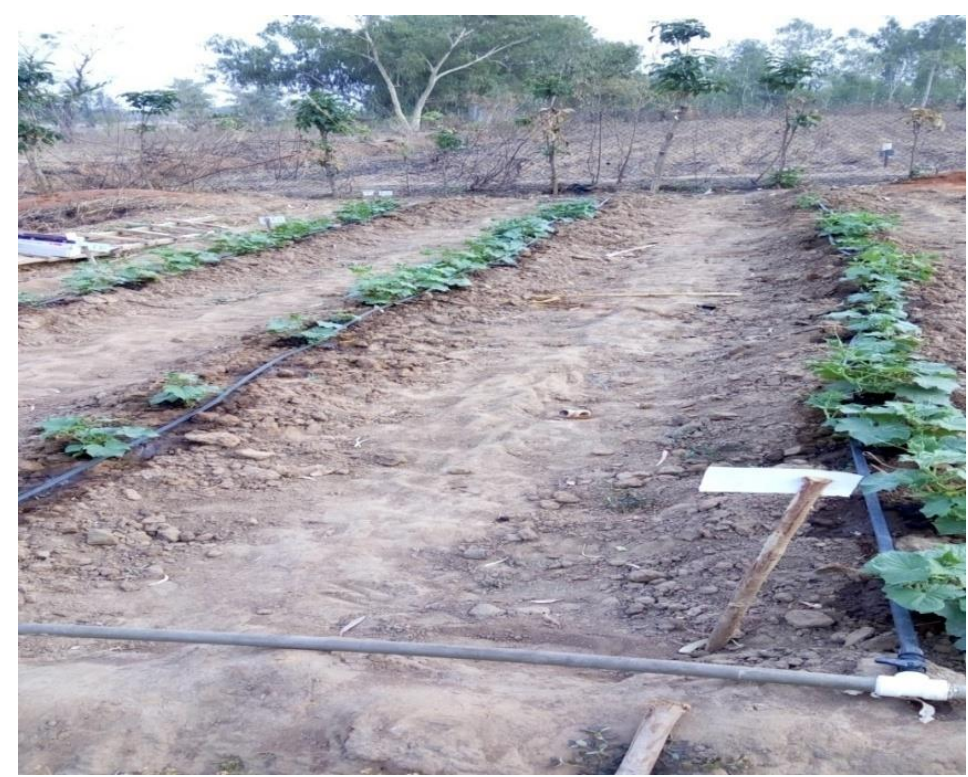

Figure 1: A section of the drip-irrigated cucumber experimental field

Water applied was based on reference evapotranspiration (ETo) by means of pan evaporation measurements within the experimental field area (Figure 2). The ETo was measured using the relationship:

$$
\mathrm{ET}_{\mathrm{o}}=\mathrm{K}_{\mathrm{p}} \times \mathrm{E}_{\mathrm{pan}}
$$

where, $\mathrm{ET}_{0}=$ Reference evapotranspiration $(\mathrm{mm} /$ day $) ; K_{p}=$ pan co-efficient; $E_{p a n}=$ daily evapotranspiration ( $\mathrm{mm}$ )

The drip irrigation running time required to satisfy the irrigation water requirements per treatment was as calculated by Nega [18]:

$$
\mathrm{T}_{\text {drip }}=\frac{\mathrm{N}_{\mathrm{p}} \mathrm{V}}{\mathrm{N}_{\mathrm{e}} \mathrm{Q} \times \mathrm{EU}}
$$

where, $T$ drip $=$ Drip Irrigation time (hours); $\mathrm{Np}=$ Number of plants served by one lateral; $\mathrm{V}=$ Volume of water applied per plant in drip irrigation system (litre); $\mathrm{Ne}=$ Number of emitter in one lateral; $\mathrm{Q}=$ Average emitter discharge (litre/hr); EU = Emission uniformity (fraction).

\subsection{Determination of Water Productivity Functions}

This refers to the production of crops per unit of water used or applied. It is expressed as the weight of crop produce per unit depth of water over a unit area, that is, $\mathrm{kg} / \mathrm{m}^{3}$. Crop water productivity (WP), Eq. 5, was computed as the ratio of the crop yield to seasonal water use while the irrigation water

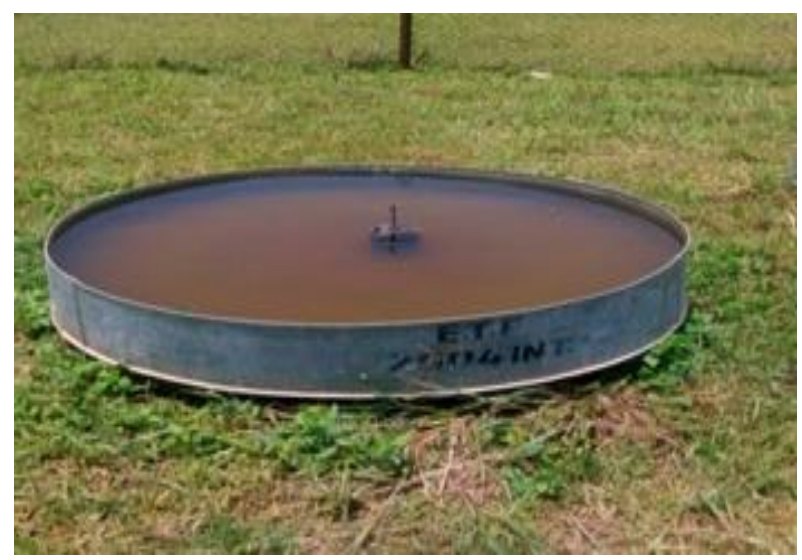

Figure 2: Evaporation pan for $E_{\text {pan }}$ measurement 
productivity (IWP), Eq. 6, was determined as the ratio of the crop yield for a particular treatment to the applied water for that treatment [19]; [7].

$$
\begin{aligned}
& \mathrm{WP}=\frac{\mathrm{Y}}{\mathrm{ET}} \\
& \mathrm{IWP}=\frac{\mathrm{Y}}{\mathrm{IR}}
\end{aligned}
$$

where, WP = crop water productivity $\left(\mathrm{Kg} / \mathrm{m}^{3}\right), \mathrm{ET}=$ evapotranspiration $(\mathrm{mm}), \mathrm{Y}=$ crop yield $(\mathrm{Kg} / \mathrm{ha})$, IWP = irrigation water productivity, IR = amount of irrigation applied.

\subsection{Statistical Analysis}

Data obtained in the study were statistically analyzed using analysis of variance (ANOVA) by means of SARS analytical software. The treatment means were compared using the Duncan's multiple range test.

\section{RESULTS AND DISCUSSION}

The fruit yield $(\mathrm{Y})(\mathrm{t} / \mathrm{ha})$, water productivity (WP) $\left(\mathrm{Kg} / \mathrm{m}^{3}\right)$ and irrigation water productivity (IWP) $\left(\mathrm{Kg} / \mathrm{m}^{3}\right)$ with respect to seasonal water applied (SWA) (mm) and seasonal crop evapotranspiration (SCE) $(\mathrm{mm})$ are presented in Table 3, for the 2016/17 and 2017/18 seasons. The yields for each treatment were compared and found to be statistically non-significant $(P(0.9594)>0.05)$ between the seasons. The amount of SWA for both seasons were also found to be statistically nonsignificant $(P(0.2514)>0.05)$. The mean yield values for the treatments ranged between 15.5 $21.0 \mathrm{t} / \mathrm{ha}$ and $16.5-20.3 \mathrm{t} / \mathrm{ha}$ in the $2016 / 17$, 2017/18 seasons, respectively. The highest yields were produced by the treatments with $100 \% \mathrm{ET}_{\text {o }}$ daily irrigation while the least yields were those of treatments with $60 \% \mathrm{ET}$ o irrigation every four days. This showed that the yield of cucumber decreased as the SWA decreased, implying that withholding water below full irrigation has the tendency to reduce the yield. Cucumber yield varies according to the cultivars or species. Determinate cultivars grow, bloom, set fruit and mature all at the same time. The indeterminate cultivars grow, bloom, set fruits and mature continuously throughout the growing season [20]. For this reason the indeterminate cultivars produce much higher yields than the determinate ones. The indeterminate cultivars can produce as much as between 91 - $150 \mathrm{t} / \mathrm{ha}$ for greenhouse production [21], while the determinate ones yield between 15 - $30 \mathrm{t} / \mathrm{ha}$ [22]; [23]; [24].
For each season, the SCE and yields showed significant differences among the treatments as indicated by the rankings. The SCE varied between $198-310 \mathrm{~mm}$ and $225-340 \mathrm{~mm}$ in the $2016 / 17$ and $2017 / 18$ seasons, respectively. For both seasons, the highest SCE values within the ranges occurred in T1 to T3 while the lowest occurred in T7 to T9. This implied that the crop evapotranspiration reduced with increase in the moisture stress; that is, as SWA reduced.

As observed by [25], this is because moisture stress has an effect on stomatal openings of a plant, mainly causing a closure in stomata which in turn slows the rate of transpiration, thereby limiting water loss and helping to prevent the wilting effects of moisture stress.

The irrigation strategies depicted by $\mathrm{T} 1$ to $\mathrm{T} 9$ influenced the water productivity (WP) and irrigation water productivity (IWP). Deficit irrigation improved WP and IWP. The highest value of IWP was obtained as $8.3 \mathrm{Kg} / \mathrm{m}^{3}$ and $7.5 \mathrm{Kg} / \mathrm{m}^{3}$ in T7 for both $2016 / 17$ and $2017 / 18$ seasons, respectively. This indicated that the most efficient use of the irrigation water was made irrigating with $60 \% \mathrm{ET}$ 。 daily. Since T7, T8 and T9 have the same values of SWA, this would also mean that the most efficient use of the irrigation water was obtained through daily irrigations. In terms of WP, similar results $\left(8.4 \mathrm{Kg} / \mathrm{m}^{3}\right.$ and 7.6 $\mathrm{Kg} / \mathrm{m}^{3}$, for $2016 / 17$ and $2017 / 18$, respectively) were obtained, showing that, consumptively, irrigating with $60 \%$ ETo (equivalent to $207 \mathrm{~mm}$ and $235 \mathrm{~mm}$ for 2016/17 and 2017/18, respectively) gave the optimum crop water use. The WP results obtained in this study are about $40 \%$ of that obtained by [26] and [27] in a similar study under greenhouse condition. The reason for the lower WP is mainly attributable to the higher yields obtained under greenhouse conditions where indeterminate cultivars with higher and longer duration yield potentials are usually grown.

The relationships between the fruit yield and SWA as well as the SCE are linear functions as shown in Figures (3), (5) and (6) while that of yield and SWA in the $2017 / 18$ (Figure 4) is polynomial. In both seasons, the correlation coefficients, $\mathrm{R}^{2}$ for the yieldseasonal water applied (Figures 3 and 4 ) are very $\operatorname{good}\left(R^{2}>0.80\right)$ and good $\left(R^{2}=0.75\right)$.

The yield - SCE relationships for both seasons can be commonly expressed as:

$$
Y=0.34(S E T)+9.46
$$


The implication of the relationship is that for every 1 $\mathrm{mm}$ increment of seasonal crop evapotranspiration, a fruit yield $0.34 \mathrm{t} / \mathrm{ha}$ would be obtained.

\section{CONCLUSION}

Drip-irrigated cucumber produced highest yield under full irrigation and decreased with deficit irrigation. Under full irrigation the yield was not statistically different irrespective of varied irrigation frequencies and the crop water productivity was highest with daily irrigation.

Within the limit of the data in this study, the highest water productivity was obtained in a deficit irrigation treatment with the least irrigation frequency.

Table 3: Seasonal irrigation depth, crop evapotranspiration, water and irrigation water use efficiencies of cucumber plant (2016/17 and 2017/18 seasons)

\begin{tabular}{ccccccccccc}
\hline \multirow{2}{*}{ Treatment } & \multicolumn{9}{c}{ 2016/2017 season } & \multicolumn{5}{c}{$2017 / 2018$ season } \\
& SWA & SCE & Yield & WP & IWP & SWA & SCE & Yield & WP & IWP \\
\hline T1 & 347 & $310 \mathrm{a}$ & $21.0 \mathrm{a}$ & 6.8 & 6.0 & 391 & $340 \mathrm{a}$ & $20.3 \mathrm{a}$ & 6.0 & 5.2 \\
T2 & 347 & $308 \mathrm{a}$ & $20.3 \mathrm{a}$ & 6.6 & 5.9 & 391 & $315 \mathrm{~b}$ & $19.8 \mathrm{a}$ & 6.3 & 5.1 \\
T3 & 347 & $289 \mathrm{~b}$ & $18.8 \mathrm{ab}$ & 6.5 & 5.4 & 391 & $311 \mathrm{~b}$ & $18.8 \mathrm{ab}$ & 6.0 & 4.8 \\
T4 & 277 & $266 \mathrm{c}$ & $19.8 \mathrm{a}$ & 7.4 & 7.1 & 313 & $287 \mathrm{c}$ & $19.0 \mathrm{ab}$ & 6.6 & 6.1 \\
T5 & 277 & $259 \mathrm{c}$ & $19.0 \mathrm{ab}$ & 7.4 & 6.9 & 313 & $270 \mathrm{~d}$ & $18.0 \mathrm{~b}$ & 6.7 & 5.8 \\
T6 & 277 & $246 \mathrm{~d}$ & $18.5 \mathrm{~b}$ & 7.5 & 6.6 & 313 & $269 \mathrm{~d}$ & $18.3 \mathrm{~b}$ & 6.8 & 5.8 \\
T7 & 207 & $205 \mathrm{e}$ & $17.3 \mathrm{~b}$ & 8.4 & 8.3 & 235 & $232 \mathrm{e}$ & $17.5 \mathrm{bc}$ & 7.6 & 7.5 \\
T8 & 207 & $200 \mathrm{e}$ & $15.8 \mathrm{c}$ & 7.9 & 7.6 & 235 & $230 \mathrm{e}$ & $17.3 \mathrm{c}$ & 7.5 & 7.4 \\
T9 & 207 & $198 \mathrm{e}$ & $15.5 \mathrm{c}$ & 7.8 & 7.5 & 235 & $225 \mathrm{e}$ & $16.5 \mathrm{c}$ & 7.3 & 7.0 \\
\hline
\end{tabular}

Means followed by the same letter(s) in a column are not significantly different at $5 \%$ level of significance.

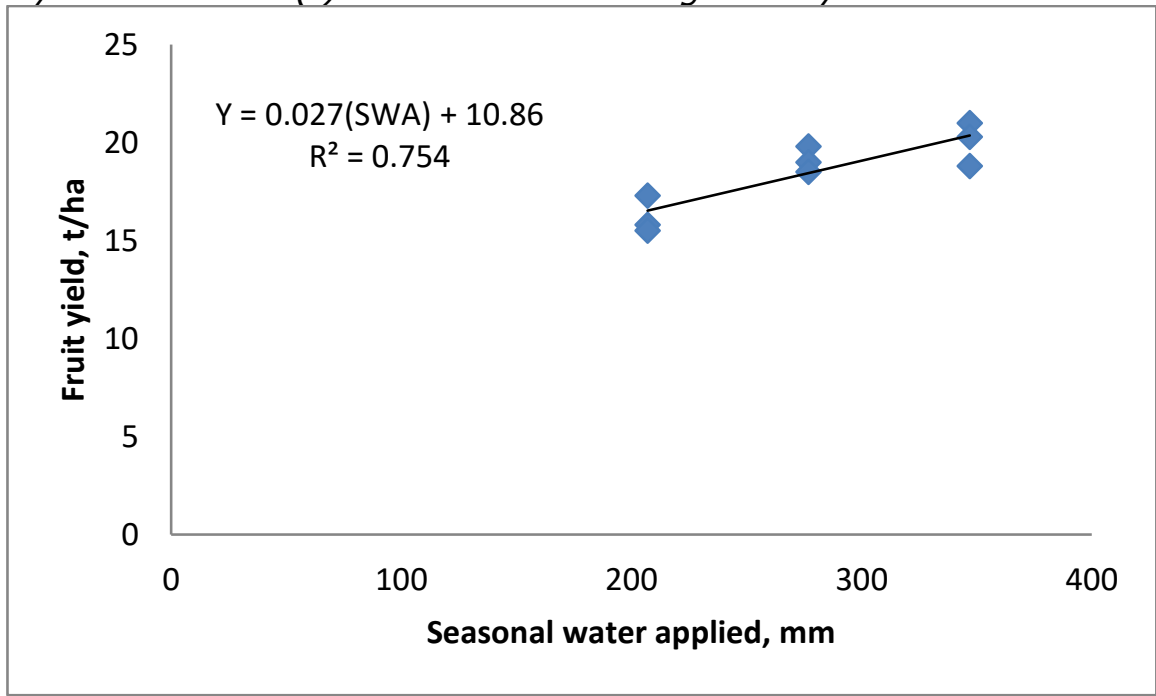

Figure 3: Yield - seasonal water applied relationship (2016/17)

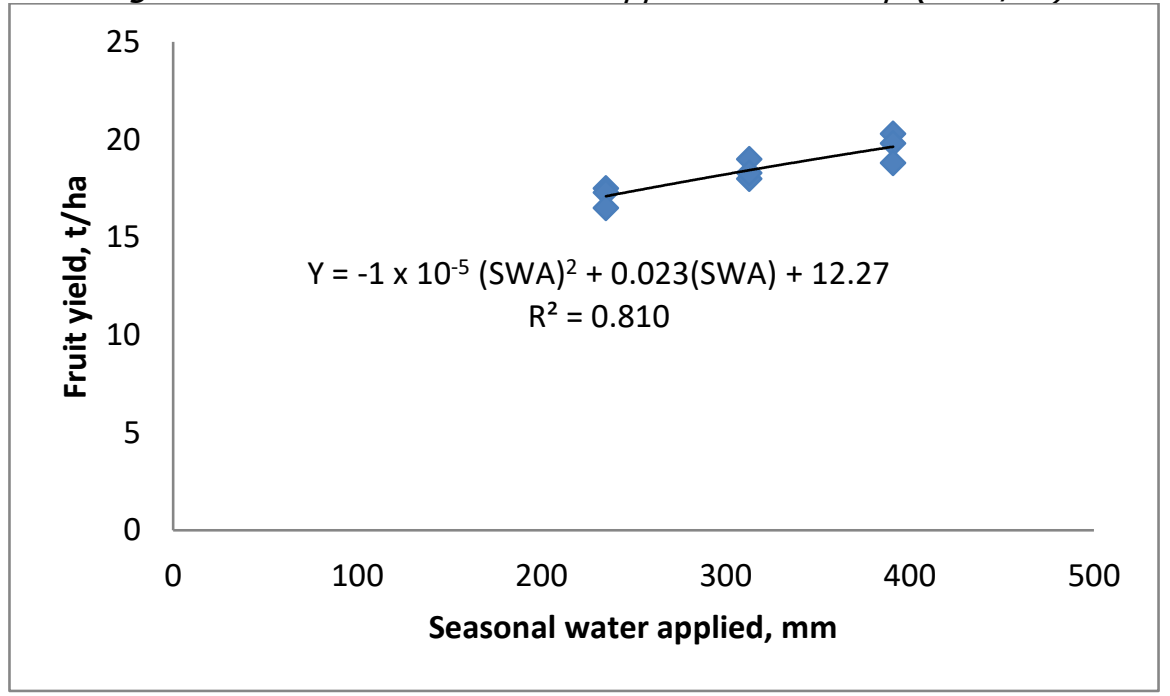

Figure 4: Yield - seasonal water applied relationship (2017/18) 


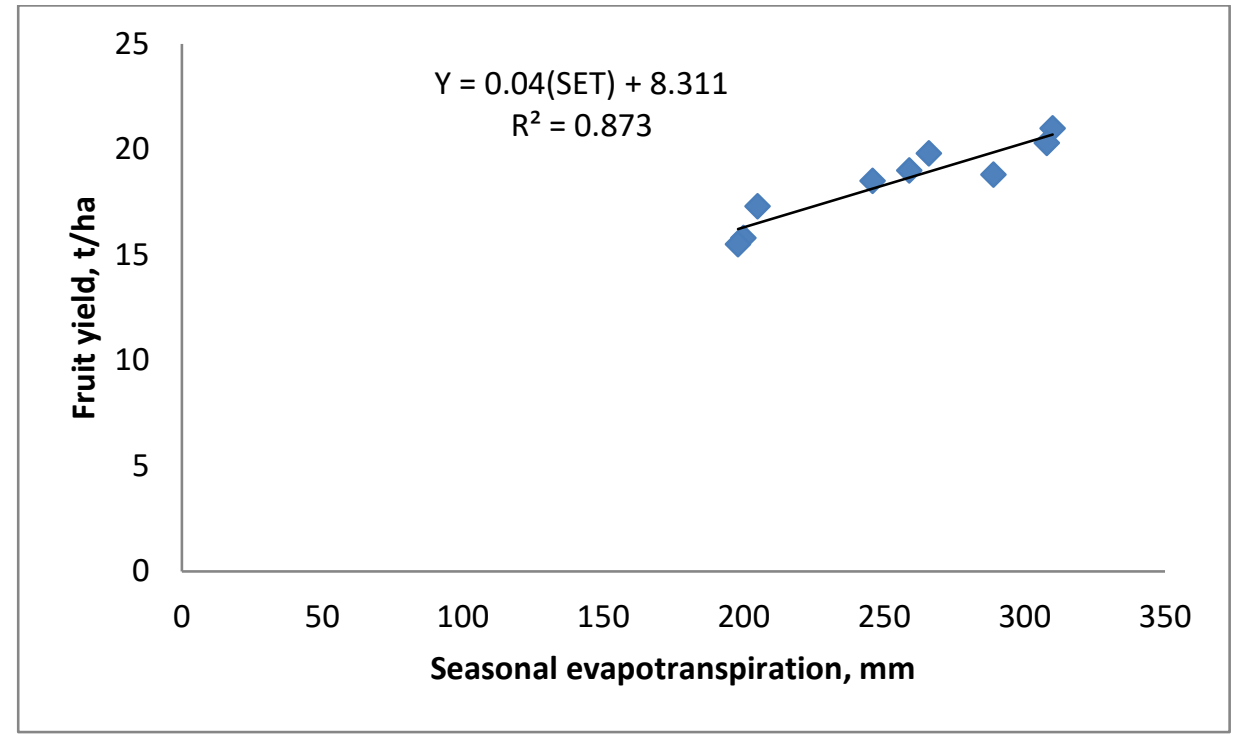

Figure 5: Yield - seasonal evapotranspiration relationship (2016/17 season)

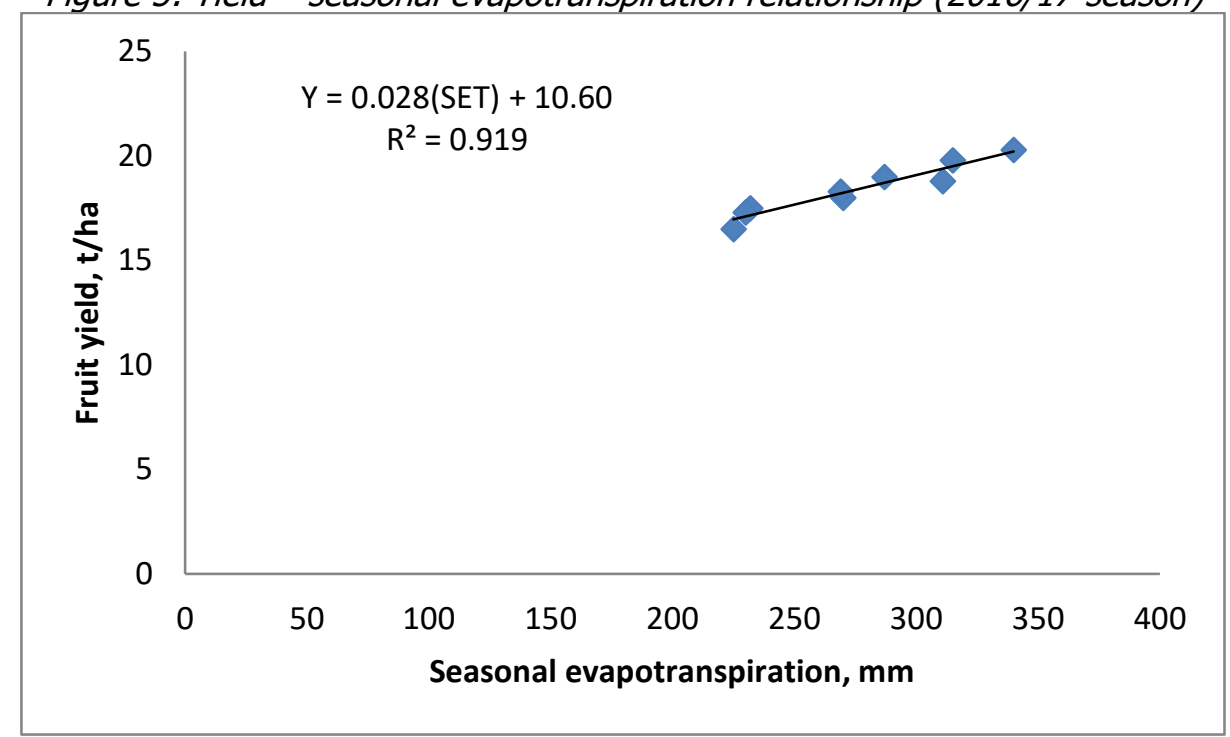

Figure 6: Yield - seasonal evapotranspiration relationship (2017/18 season)

There was marginal increase of $3.7 \mathrm{t} / \mathrm{ha}$ and $2.8 \mathrm{t} / \mathrm{ha}$ in yield resulting from marginal application of 140 $\mathrm{mm}$ and $156 \mathrm{~mm}$ of seasonal irrigation in 2016/17 and $2017 / 18$ seasons, respectively. The yield seasonal evapotranspiration relationships for both seasons suggest that for every $1 \mathrm{~mm}$ increment of seasonal crop evapotranspiration, a fruit yield 0.34 $\mathrm{t} / \mathrm{ha}$ would be obtained.

The limitations of this study are that soil fertility and the economic value of irrigation water were not considered as a factor. The results of this study will serve as a basis for the economic evaluation of the various treatments in order to recommend the most profitable practice for drip-irrigated cucumber grown in the field.

\section{REFERENCES}

[1] Oyebande, L. and Balogun, I. "Sustainable water resources management in arid countries", Canadian Journal of Sustainable Studies, Vol. 13, No. 4, 1992, pp. 209-226.

[2] Assouline, S. "The effects of micro drip and conventional drip irrigation on water distribution and uptake", Soil Sci. SCC. Am. J., Vol. 66, No. 5, 2002, pp. 1630-1636.

[3] Cao H.X., Kang S.Z. and He H. "Effects of evaporation and irrigation frequency on soil water distribution", Trans. CSAE, Vol. 19, 2003, pp. 1-4

[4] Liu M.X., Yang J.S., Li X.M., Yu M. and Wang J. "Effects of irrigation amount and frequency on soil water distribution and water use efficiency in a cotton field under mulched drip 
irrigation", Chin. J. Appl. Ecol., Vol. 22, 2011, pp. $3203-3210$

[5] Zhang G., Shen D., Ming B., Xie R., Jin X., Liu C., Hou P., Xue J., Chen J., Zhang W., Liu W., Wang K. and Li S. "Using irrigation intervals to optimize water use efficiency and maize yield in Xinjiang, Northwest China", Crop Journal, Vol. 7, No. 3, 2019, pp. 322-334

[6] Uçan K., Killi F., Gençoğlan C. and Merdun H. "Effect of irrigation frequency and amount on water use efficiency and yield of sesame under field conditions", Field Crops Research, Vol. 101, 2007, pp. 249-258

[7] Ali M.H. and Talukder M.S.U. "Increasing water productivity in crop production - A synthesis", Agricultural Water Management, Vol. 95, 2008, pp. 1201-1213.

[8] Ritchie, J. T. and Johnson B.S. "Irrigation of agricultural crops", Agronomy Monograph, No 30, 1990, pp. 363-390.

[9] Li J. and Wang X. "The present studying situation and existing problems of watersaving irrigation index for vegetable", Agric. Res. Arid Areas, Vol. 18, 2000, pp. 118-123

[10] Mao X., Liu M., Wang X., Liu C., Hou Z. and Shi J. "Effects of deficit irrigation on yield and water use of greenhouse grown cucumber in the North China Plain", Agric. Water Management, Vol. 61, 2003, pp. 219-228

[11] Larson B.C., Mossier M.A. and Nesheim O.N., "Florida crop/pest management profiles: Cucumbers. UF IFAS Extension", CR 1255, 2014

[12] Egel D.S. "Midwest vegetable production guide for commercial growers", 2016

[13] KMS. "Growers Guide: Cucumber", Kencor Management Services - Farm Shop/National Tested Seeds Pub., Zimbabwe http://www.natseeds.co.zw/growersguide/cucumber Accessed on November 18, 2019

[14] SAO. "Cucumber Planting. Vegetable farming in South Africa", South Africa Online (Pty) Ltd. http://southafrica.co.za/cucumberplanting.html Accessed on Nov. 16, 2019

[15] KOMBAT. "Kombat pest control solutions" https://www.kombat.co.za/docs products/ Cypermethrin.pdf Accessed on Mar. 2017.

[16] Onwuegbunam D.O., Onwuegbunam N.E., Oiganji E. and Saifullah A. "Emission Uniformity and Gasoline Pump Fuel Use of a Pressurized Drip Irrigation System as Affected by Operating Pressure, Lateral Run Length and Irrigation Running Time", Production Agriculture and Technology (PAT) Journal, Vol. 15, No. 1, 2019; pp. 84-93.

[17] Michael A.M. Irrigation Theory and Practice, $2^{\text {nd }}$ Ed.Vikas Publishing House PVT Ltd, New Delhi, 2009, pp. 525-528

[18] Nega H. "Effect of deficit irrigation and mulch on water use and yield of drip irrigated onion", Unpublished M.Sc. Thesis. Department of Agricultural Engineering. Ahmadu Bello University, Zaria, Nigeria, 2009.

[19] Howell T.A. "Enhancing water use efficiency in irrigated agriculture", Agron. J., Vol. 93, No. 2, 2001, pp. 281-287.

[20] Servadio B. "Cool cucumber", Master gardener newspaper articles, UCCE, pp. 1-2 https://ucanr.edu/datastoreFiles/268-580.pdf Accessed on Feb. 15, 2017.

[21] Alomran A.M. and Luki I.I. "Effects of deficit irrigation on yield and water use of grown cucumbers in Saudi Arabia", WIT Transactions on Ecology and the Environment, Vol. 168, 2012, pp. 353-358.

[22] Eifediyi E.K. and Remison S.U. "Effect of time of planting on growth and yield of five varieties of cucumber", Report and Opinion, Vol. 1, No. 5, 2009, pp. 81-90

[23] Ojeifo I.M., Nzekwe U. and Akpovwovwo. Growth and yield of five varieties of cucumber in Southern Nigeria. Journal of Agriculture, Forestry and Social Science, Vol. 6, No. 2, 2008.

[24] DARD. "Expected yields", Department of Agriculture and Rural Development, Province of Kwazulu-Natal, https://www.kzndard. gov.za/images/Documents/ Horticulture/ Veg prod/expected yields.pdf Accessed on April 25, 2017.

[25] Freeman S. Biological Science: $5^{\text {th }}$ Edition. USA: Pearson Education, Inc., 2014

[26] Hamza A.A. and Almasraf S.A. "Evaluation of the yield and water use efficiency of cucumber inside greenhouses", Journal of Babylon University/Engineering Sciences, Vol. 24, No. 1, 2016, pp. 95-106.

[27] Yaghi T., Arslan A. and Naoum F. "Cucumber water use efficiency under plastic mulch and drip irrigation" Agricultural Water Management, Vol. 128, 2013, pp. 149-157 